\section{CORONER FOR MIDDLESEX.}

IETTER FROM JOSEPH HUME, ESQ., M. P., TO MR. WAKLEY.

Arbroath, August 26th, 1830.

Dear Sir,-I am favoured with your letter announcing your intention to of $\mathrm{r}$ yourself a Candidate for the office of Coroner for Middlesex, now vacant, and hasten to assure you, that $I$ have long been of opinion that that office, generally, has heen filled by men not calculated to perform the duties which are required of $i t$.

I consider that no man should fill the office of coroner, who has not attended a course of Medical jurisprudence; and if, to that very important branch of education, a general Medical education is superadded, the public would have a better chance of that protection, which it is the intention of that office to afford to the community.

In appointing a judge to any court, it is considered necessary by the Minister who has the appointment, to ascertain whethe the person applying has been educated so as to fit him for performing the duties of the court; and a properly-founded complaint would be made against that Minister, who would venture to appoint an uneducated, and consequently, unfit person to any court. The Coroner is the head of a court, and has the direction of that examination which shall enable the jury to determine, whether the deceased has died a natural or violent death; and the want of that education which I have pointed ont, must often be attended with very mischierous efrects to society.

I have known inquests where, as appeared to me, innocent persons have been arraigned for supposed injury to the deceased; and I bave seen others, where the cleurest case was made out anainst individuals who were allowed to escape.

With these opinions, I am glad that a properly-educated gentleman has offered himself for the office of coroner, and I hope the freeholders of Middlesex will take these matters into consideration, and by a proper selection afrond that hope of protection which the uffice ought to hold out.

I should be glad to aid in any way the Committee that has been formed to promote your election, and only regret that I am not in Middlesex to assist their efforts.

I am, your obedient serrant,

JosepH Hume.

To T. Wakley, Esq.

35, Bedford Square.
Joumal of a Naturalist.-Third edition!

London, Murray. 1830.

$W_{E}$ have received a specimen of a newlyinvented narcotic preparation, labelled as above, for which a patent has been recently obtained; we have submitted it to numerous and varied clinical experiments, and find that, even under the most untoward circumstances, it never fails to induce narcotism, when administered in moderate doses.-From opium, and the ordinary remedies of this class, it differs in aeting as a direct sedative, and never producing even the most transitory excitement; it contains, besides, no crystalline principle analogous to morphia, for though we have subjected it to the most rigid analysis, yet we have been unable to separate any brilliant or prismatic ingredient; on the whole, we have reason to believe, that its hypnotic properties depend entirely on extractive matter, inseparably associated with lignin and caoutchouc.

But to descend from our pharmacentical cothurni. We have actually read this book, despite of all its drowsy exhalations; we warn our readers, however, if they value their lives, not to attempt the repetition of our chivalrous achievement. The work purports to be the Journal of a Naturalist residing in Gloucestershire, and is evidently; though not confessedly, an imitation of the celebrated and admired natural history of Selborne, by Mr. White. Though from the nature of his observations, a Journalist can seldom be expected to conform to the regulations of style, or to move in the harness of arrangement, yet we were scarcely prepared to encounter so chaotic an accumulation of materials as this volume presented. As indefinite as the "beau ideal" of an Act of Parliament, it contains but one chapter, withont section, or subdivision, from the title-page to the printer's name; while, as far as regards the assortment of the ingredients, never did Harlequin assume his Protean disguises with more perplexing mutability, than that with which our author hurries us onwards from subject to subject, no matter how opposite they may be in nature, setting memory at defiance without communicating either instruction or delight.-His phraseology, throughout, is of the most inflated description, ever aiming at, but never reaching, the pathetic or sublime. He is evidently a Rhapsodist in his 303 